University of Nebraska - Lincoln

DigitalCommons@University of Nebraska - Lincoln

1982

EFFECTS OF CONTRASTING PHOTOPERIODS AND

TEMPERATURES ON PERFORMANCE TRAITS OF CONFINEMENTREARED EWE LAMBS

B. D. Schanbacher

USDA-ARS

G. L. Hahn

United States Department of Agriculture, hahn@email.marc.usda.gov

J. A. Nienaber

United States Department of Agriculture, john.nienaber@ars.usda.gov

Follow this and additional works at: https://digitalcommons.unl.edu/usdaarsfacpub

Part of the Agricultural Science Commons

Schanbacher, B. D.; Hahn, G. L.; and Nienaber, J. A., "EFFECTS OF CONTRASTING PHOTOPERIODS AND TEMPERATURES ON PERFORMANCE TRAITS OF CONFINEMENT-REARED EWE LAMBS" (1982).

Publications from USDA-ARS / UNL Faculty. 762.

https://digitalcommons.unl.edu/usdaarsfacpub/762

This Article is brought to you for free and open access by the U.S. Department of Agriculture: Agricultural Research Service, Lincoln, Nebraska at DigitalCommons@University of Nebraska - Lincoln. It has been accepted for inclusion in Publications from USDA-ARS / UNL Faculty by an authorized administrator of DigitalCommons@University of Nebraska - Lincoln. 


\title{
EFFECTS OF CONTRASTING PHOTOPERIODS AND TEMPERATURES ON PERFORMANCE TRAITS OF CONFINEMENT-REARED EWE LAMBS ${ }^{1}$
}

\author{
B. D. Schanbacher, G. L. Hahn and J. A. Nienaber
}

US Department of Agriculture 2,3 , Clay Center, NE 68933

\begin{abstract}
Summary
The effects of contrasting photoperiods (16L:8D vs $8 \mathrm{~L}: 16 \mathrm{D})$ and ambient temperatures ( $5 \mathrm{C}$ vs $18 \mathrm{C}$ vs $31 \mathrm{C}$ ) on performance traits of ewe lambs have been evaluated. Seventy-two lambs were paired and allotted to one of six treatment groups in a $2 \times 3$ factorial experiment. The lambs were fed a pelleted diet ad libitum. throughout the 14-wk study (i.e., as lambs progressed from 12 to 26 wk of age). Analysis of performance and carcass data showed that both photoperiod and temperature affected growth rate $(P<.01)$, feed intake $(P<.01)$, final weight $(P<.01)$ and carcass weight $(P<.01)$. Although feed efficiency tended to be greater for lambs exposed to the $16 \mathrm{~L}: 8 \mathrm{D}$ photoperiod, this characteristic was not affected significantly. An interaction between photoperiod and temperature was not observed for growth rate, final weight or carcass weight. Final weight and carcass weight for lambs in the six treatment groups were: 52.5 and $27.7 \mathrm{~kg}$ for $16 \mathrm{~L}: 8 \mathrm{D}, 5 \mathrm{C}$; 49.2 and $25.8 \mathrm{~kg}$ for $8 \mathrm{~L}: 16 \mathrm{D}, 5 \mathrm{C} ; 48.1$ and $25.3 \mathrm{~kg}$ for $16 \mathrm{~L}: 8 \mathrm{D}, 18 \mathrm{C} ; 45.2$ and $23.5 \mathrm{~kg}$ for $8 \mathrm{~L}: 16 \mathrm{D}, 18 \mathrm{C} ; 42.0$ and $21.1 \mathrm{~kg}$ for $16 \mathrm{~L}: 8 \mathrm{D}$, $31 \mathrm{C}$ and 36.0 and $17.4 \mathrm{~kg}$ for $8 \mathrm{~L}: 16 \mathrm{D}, 31 \mathrm{C}$. Carcass merit, including quality and yield, was not affected $(P>.05)$ by treatment. Whereas serum prolactin concentrations were elevated in lambs exposed to the $16 \mathrm{~L}: 8 \mathrm{D}$ photoperiod, an
\end{abstract}

\footnotetext{
${ }^{1}$ The authors wish to acknowledge Mr. Bruce Larsen, Mr. Allen Maddy and Mr. Wei Wu for technical assistance during the study; Mr. Michael MacNeil and Ms. Becky Bauer for helping with the statistical analyses, and cooperation of the Nebraska Agr. Exp. Sta., Univ. of Nebraska, Lincoln.

${ }^{2}$ Roman L. Hruska U.S. Meat Animal Research. Center, ARS.

${ }^{3}$ Mention of trade names or companies does not constitute an implied warranty or endorsement by the authors or USDA.
}

interaction $(\mathrm{P}<.01)$ between photoperiod and temperature was found. Wool growth was similar for lambs exposed to $16 \mathrm{~L}: 8 \mathrm{D}$ and 8L:16D photoperiods, but was reduced $(\mathrm{P}<.05)$ by exposure to increasing environmental temperatures. These results suggest that environmental temperature and photoperiod independently contribute to the growth and performance of confinement-reared ewe lambs and that each of these variables can be adjusted to optimize the efficiency of lamb production.

(Key Words: Ewe Lambs, Photoperiod-Temperature, Environment, Growth, Performance.)

\section{Introduction}

Numerous environmental factors, acting separately or collectively, affect animal performance and the efficiency of livestock production. Ambient temperature and photoperiod are two factors believed to significantly affect performance of the growing-finishing lamb. Air temperature, particularly above the thermoneutral zone, results in one or more physiological adjustments that may adversely affect performance (Soderquist and Knox, 1967; Knox, 1976); however, unshorn sheep tolerate cold environments extremely well (Webster, 1976). In contrast to short photoperiods (8L:16D), long photoperiods (16L:8D) increase the growth rates of both ram and wether lambs (Schanbacher and Crouse, 1980; 1981).

A factorial experiment was conducted to determine the effects of environmental temperature and photoperiod on performance traits of market lambs. An evaluation of these environmental constraints provides a better understanding of normal seasonal variation in lamb performance and provides a basis for selecting those environmental conditions that improve the overall efficiency of lamb production. This information is important for design and man- 
agement of confinement facilities to be used in intensified sheep production systems.

\section{Materials and Methods}

Treatments. Seventy-two unshorn crossbred ewe lambs were weaned at about 10 wk of age, stratified by age and weight, and randomly assigned to one of six treatment groups. The twelve lambs in each group were subsequently paired. Each pair of lambs was placed in a 1.2 $X 1.2 \mathrm{~m}$ pen in an experimental chamber maintained at ambient temperature $(18 \mathrm{C})$ and photoperiod (12L:12D) for a 2-wk adaptation period. The environmental conditions were then changed for each treatment group and the study began. The following conditions were imposed for a 14-wk treatment period: group I, 16L:8D, 5 C; group II, 8L:16D, 5C; group III, $16 \mathrm{~L}: 8 \mathrm{D}, 18 \mathrm{C}$; group IV, 8L:16D, 18C; group $\mathrm{V}, 16 \mathrm{~L}: 8 \mathrm{D}, 31 \mathrm{C}$; group $\mathrm{VI}, 8 \mathrm{~L}: 16 \mathrm{D}, 31 \mathrm{C}$. Artificial lighting was provided daily between 0700 and $2300 \mathrm{~h}(16 \mathrm{~L}: 8 \mathrm{D})$ or 0700 and 1500 h (8L:16D). Actual ambient temperatures achieved in the respective treatments were 7.8 , 18.6 and $32.6 \mathrm{C}$.

Initial body weights were recorded and the fleece removed from an area over the left rib cage when the study began. A pelleted diet consisting of $60 \%$ ground shelled corn (IFN 4-02931), $20 \%$ alfalfa hay (IFN 1-00-063) and $15 \%$ soybean meal (IFN 5-04-604) and analyzed to contain $89.7 \%$ dry matter, $17.1 \%$ crude protein and $78.6 \%$ total digestible nutrients was fed ad libitum. Feeders were filled daily between 0800 and 0900 h. Feed consumption was tabulated for each pen, body weights were recorded and blood samples were collected by jugular venipuncture at weekly intervals for the next 14 wk.

At the end of the experiment, each lamb was weighed (average slaughter weight, $46 \mathrm{~kg}$ ) and a $100 \mathrm{~cm}^{2}$ patch of wool was removed from the previously clipped area, washed, dried and then weighed. Carcass weights and other carcass data were recorded at a commercial slaughter facility and USDA quality and yield grades were calculated.

Serum prolactin concentrations were determined for all samples by a double antibody radioimmunoassay (Schanbacher and Ford, 1979; Schanbacher, 1980). Assay sensitivity was $1 \mathrm{ng}$ NIH-P-S8/ml. The intraassay coefficient of variation among duplicates was $<12 \%$.

Statistical Analyses. Performance and carcass data were analyzed by analysis of covariance using the method for least-squares with unequal subclass numbers (Harvey, 1975). The model included the main effects (treatment) of temperature and photoperiod. Initial weight was included as a covariate when analyzing performance traits and carcass weight, whereas carcass weight was included as a covariate when analyzing aspects of carcass merit. Orthogonal contrasts were applied when treatment effects were significant. The interaction of photoperiod effects with linear and quadratic temperature effects were tested. A split-plot analysis of variance (Steel and Torrie, 1960) was used to evaluate statistical differences in growth rates and serum prolactin concentrations because these characteristics constituted repeated observations on each animal.

\section{Results}

Shown in table 1 is the summary of analyses of covariance for performance and carcass traits of confinement-reared ewe lambs exposed to contrasting environments. Photoperiod and (or) temperature affected all characteristics studied except for the carcass attributes of percentage kidney-pelvic fat, backfat thickness and USDA quality and yield grade. Photoperiod effects were limited to comparisons between long (16L:8D) and short (8L:16D) daylengths, whereas temperature effects were evaluated at 5,18 and $31 \mathrm{C}$. Temperature effects were partitioned into both linear $\left(T_{1}\right)$ and quadratic $\left(T_{q}\right)$ components. Quadratic temperature effects were observed for most aspects of performance over the $26 \mathrm{C}$ range studied. Interactions between photoperiod and the linear effects of temperature $\left(P \times T_{1}\right)$ were observed for feed intake and serum prolactin. Significant interactions of photoperiod with the quadratic effects of temperature $\left(P \times T_{q}\right)$ were not observed for any characteristic measured.

Least-squares means for performance traits of ewe lambs exposed to contrasting photoperiodtemperature environments are presented in table 2. Initial weight averaged $21.2 \mathrm{~kg}$ for the lambs in this study. An average daily gain of $251 \mathrm{~g} / \mathrm{d}$ resulted in a mean slaughter weight of $45.7 \mathrm{~kg}$. Treatment means for average daily gain, instead of periodic gains, are presented (table 2) because growth rates did not differ across time within treatment group. The most rapid gains were observed for lambs exposed to the $16 \mathrm{~L}: 8 \mathrm{D}$ photoperiod and $5 \mathrm{C}$ temperature 
TABLE 1. OBSERVED SIGNIFICANCE LEVELS FOR ORTHOGONAL CONTRASTS OF TREATMENT EFFECTS

\begin{tabular}{|c|c|c|c|c|c|}
\hline \multirow[b]{2}{*}{ Dependent variable } & \multicolumn{4}{|c|}{ Hypotheses ${ }^{\mathbf{a}}$} & \multirow[b]{2}{*}{$P \times T_{q}$} \\
\hline & $\mathbf{P}$ & $\mathbf{T}_{1}$ & $T_{q}$ & $P \times T_{1}$ & \\
\hline Avg daily gain & $* *$ & $* *$ & $*$ & NS & NS \\
\hline Feed intake & $* *$ & $* *$ & NS & $*$ & NS \\
\hline Feed efficiency & $\mathbf{N S}^{\mathrm{c}}$ & $*$ & $*$ & NS & NS \\
\hline Final weight & $* *$ & $* *$ & $*$ & NS & NS \\
\hline Carcass weight & $* *$ & $* *$ & $* *$ & NS & NS \\
\hline Carcass attributes $b$ & NS & NS & NS & NS & NS \\
\hline Serum prolactin & $* *$ & $* *$ & $*$ & $* *$ & NS \\
\hline Wool Growth & NS & $*$ & NS & NS & NS \\
\hline
\end{tabular}

\footnotetext{
${ }^{a_{P}}=$ test for photoperiod effects; $T_{1}=$ test for linear effects of temperature; $T_{q}=$ test for quadratic effects of temperature; $P \times T_{1}$ and $P \times T_{q}=$ test for interactions.

${ }^{b}$ Carcass attributes include percentage kidney-pelvic fat, backfat thickness, quality grade and yield grade.

$\mathrm{c}_{\mathrm{NS}}=$ nonsignificant .

$* \mathrm{P}<.05$.

$* * \mathrm{P}<.01$.
}

environment. Averaged across temperatures, the growth rate for lambs exposed to the 16-h photoperiod $(269 \mathrm{~g} / \mathrm{d})$ was about $15 \%$ greater than for lambs exposed to only $8 \mathrm{~h}$ of light $/ \mathrm{d}$ $(228 \mathrm{~g} / \mathrm{d})$. Ambient temperature was also found to be an important determinant of growth rate in lambs. An inverse relationship between environmental temperature and average daily gain (ADG) is illustrated in the regression equation determined for the lambs in this study [ADG $=327.3-4.46(\mathrm{C})]$. This relationship is also apparent following inspection of the subclass means of table 2 . Note the twofold differential in growth rate of lambs exposed to the extreme environments, i.e., group $I$ and group VI lambs.

Growth rates were closely paralleled by differences in feed intake (table 2). Although feed intake was similar for lambs exposed to long and short photoperiods at $5 \mathrm{C}$, the differential effects of photoperiod were more noticeable at the two higher temperatures. The regression equations for temperature effects on daily feed intake (FI) were $\mathrm{FI}=1.77+.010(\mathrm{C})$ $-.0009\left(\mathrm{C}^{2}\right)$ for lambs exposed to the 16L:8D photoperiod and FI $=1.88-.022$ (C) -.0003

TABLE 2. LEAST-SQUARES MEANS ( \pm SE) FOR PERFORMANCE TRAITS OF EWE LAMBS EXPOSED TO CONSTRASTING PHOTOPERIOD-TEMPERATURE ENVIRONMENTS ${ }^{a}$

\begin{tabular}{lllll}
\hline Treatment & $\begin{array}{l}\text { Avg daily } \\
\text { gain, g/d }\end{array}$ & $\begin{array}{l}\text { Total feed } \\
\text { intake, kg/penc }\end{array}$ & $\begin{array}{l}\text { Feed efficiency, } \\
\mathrm{kg} \mathrm{feed} / \mathrm{kg} \text { gain }\end{array}$ & $\begin{array}{l}\text { Final wt, } \\
\mathrm{kg}\end{array}$ \\
\hline I (16L:8D, 5 C) & $320 \pm 8$ & $327 \pm 16$ & $5.8 \pm .5$ & $52.5 \pm .8$ \\
II (8L:16D, 5 C) & $287 \pm 8$ & $321 \pm 16$ & $6.1 \pm .5$ & $49.2 \pm .8$ \\
III (16L:8D, 18 C) & $275 \pm 9$ & $304 \pm 16$ & $5.7 \pm .5$ & $48.1 \pm .9$ \\
IV (8L:16D, 18 C) & $245 \pm 9$ & $249 \pm 16$ & $5.4 \pm .5$ & $45.2 \pm .9$ \\
V (16L:8D, 31 C) & $213 \pm 9$ & $228 \pm 16$ & $6.2 \pm .5$ & $42.0 \pm .9$ \\
VI (8L:16D, 31 C) & $152 \pm 10$ & $156 \pm 16$ & $7.7 \pm .5$ & $36.0 \pm .9$ \\
\hline
\end{tabular}

\footnotetext{
${ }^{a}$ Means adjusted for initial weight by analysis of covariance.

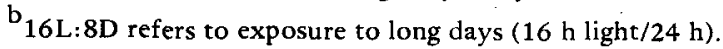

$8 \mathrm{~L}: 16 \mathrm{D}$ refers to exposure to short days ( $8 \mathrm{~h} \mathrm{light} / 24 \mathrm{~h}$ ).

${ }^{\mathrm{c}}$ Feed intake for paired lambs over the 14-wk treatment period.
} 
TABLE 3. LEAST-SQUARES MEANS ( \pm SE) FOR CARCASS TRAITS OF EWE LAMBS EXPOSED TO CONTRASTING PHOTOPERIOD-TEMPERATURE ENVIRONMENTS ${ }^{\mathrm{a}}$

\begin{tabular}{llllll}
\hline Treatment & Carcass wt, & $\begin{array}{l}\text { Kidney-pelvic } \\
\text { fat, } \%\end{array}$ & $\begin{array}{l}\text { Backfat thickness, } \\
\text { mm }\end{array}$ & Quality gradec & Yield graded \\
\hline I (16L:8D, 5 C) & $27.67 \pm .49$ & $5.10 \pm .71$ & $9.60 \pm 1.30$ & $11.35 \pm .44$ & $4.85 \pm .44$ \\
II (8L:16D, 5 C) & $25.79 \pm .49$ & $6.30 \pm .55$ & $9.06 \pm 1.01$ & $10.91 \pm .34$ & $5.02 \pm .34$ \\
III (16L:8D, 18 C) & $25.31 \pm .5 ?$ & $5.25 \pm .56$ & $9.04 \pm 1.04$ & $10.74 \pm .35$ & $4.75 \pm .35$ \\
IV (8L:16D, 18 C) & $23.51 \pm .52$ & $6.10 \pm .50$ & $10.35 \pm .92$ & $11.70 \pm .31$ & $5.30 \pm .31$ \\
V (16L:8D, 31 C) & $21.05 \pm .56$ & $5.73 \pm .54$ & $9.72 \pm .99$ & $11.33 \pm .34$ & $5.06 \pm .33$ \\
VI (8L:16D,31 C) & $17.37 \pm .56$ & $6.26 \pm .99$ & $11.33 \pm 1.83$ & $12.26 \pm .62$ & $5.63 \pm .61$ \\
\hline
\end{tabular}

\footnotetext{
${ }^{a}$ Carcass weight means adjusted for initial weight by analysis of covariance; means for carcass traits adjusted for carcass weight differences by analyses of covariance.

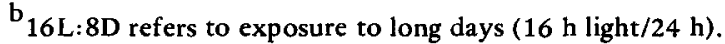

$8 \mathrm{~L}: 16 \mathrm{D}$ refers to exposure to short days $(8 \mathrm{~h}$ light $/ 24 \mathrm{~h}$ ).

${ }^{\mathrm{c}}$ Quality grade: $10=$ low Choice, $11=$ average Choice, $12=$ high Choice.

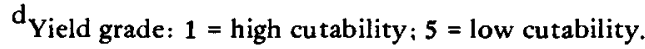

$\left(C^{2}\right)$ for lambs exposed to the $8 \mathrm{~L}: 16 \mathrm{D}$ photoperiod, respectively.

The effects of photoperiod on conversion of feed to live weight gain approached significance with lambs exposed to the 16-h photoperiod showing the best efficiency. Temperature effects on feed efficiency showed both a linear and a quadratic component (table 1). Interestingly, lambs converted feed to live weight gain most efficiently at both photoperiods when exposed to the $18 \mathrm{C}$ environment. Interaction effects of photoperiod and temperature $\left(P \times T_{1}\right.$ and $P \times T_{q}$ ) for feed efficiency were nonsignificant.

In this study, differences in final (slaughter) weight were reflected by differences in average daily gain. Photoperiod and temperature ef- fects were highly significant and no interactions were detected. Final weights decreased with increasing temperature and with the $8 \mathrm{~L}: 16 \mathrm{D}$ photoperiod. Treatment differences in final weight (table 2) were closely paralleled by differences in hot carcass weight (table 3 ). Whereas dressing percentage (carcass weight/ final weight $\times 100$ ) was similar across photoperiods, dressing percentage tended to be lower for lambs exposed to the $31 \mathrm{C}$ environment $(-49.1 \%)$ as compared to lambs exposed to the $18 \mathrm{C}(\sim 52.3 \%)$ and $5 \mathrm{C}(\sim 52.5 \%)$ environments.

In spite of significant treatment effects on carcass weight, the characteristics of carcass merit, when adjusted for differences in carcass weight, were not significantly affected. Treatment means for percentage kidney-pelvic fat,

TABLE 4. LEAST-SQUARES MEANS ( \pm SE) FOR SERUM PROLACTIN CONCENTRATION AND WOOL GROWTH CHARACTERISTICS OF EWE LAMBS EXPOSED TO CONTRASTING PHOTOPERIOD-TEMPERATURE ENVIRONMENTS

\begin{tabular}{lrr}
\hline \hline & $\begin{array}{l}\text { Serum prolactin, } \\
\text { Treatment }\end{array}$ & $\begin{array}{l}\text { Wool growth, } \\
\mathrm{mg}^{\mathrm{a}} \mathrm{cm}^{2}\end{array}$ \\
\hline I (16L:8D, 5 C) & $671 \pm 61$ & $107 \pm 7$ \\
II (8L:16D, 5 C) & $316 \pm 61$ & $115 \pm 6$ \\
III (16L:8D, 18 C) & $1,077 \pm 61$ & $94 \pm 6$ \\
IV (8L:16D, 18 C) & $387 \pm 62$ & $111 \pm 6$ \\
V (16L:8D, 31 C) & $1,236 \pm 62$ & $86 \pm 5$ \\
VI (8L:16D, 31 C) & $241 \pm 63$ & $86 \pm 9$ \\
\hline
\end{tabular}

${ }^{2} 16 \mathrm{~L}: 8 \mathrm{D}$ refers to exposure to long days ( $16 \mathrm{~h}$ light $/ 24 \mathrm{~h}$ ).

$8 \mathrm{~L}: 16 \mathrm{D}$ refers to exposure to short days $(8 \mathrm{~h}$ light $/ 24 \mathrm{~h}$ ). 
backfat thickness and USDA quality and yield grade are presented in table 3.

Serum prolactin concentrations were significantly affected by the contrasting photoperiod temperature environments. Because prolactin concentrations did not differ across time within treatment group $(P>.05)$, only overall mean concentrations are presented (table 4 ). Prolactin concentrations were elevated by exposure to the 16-h photoperiod regardless of temperature. The significant interaction $\left(P \times T_{1}\right)$ resulted from increased prolactin concentrations with increasing temperatures being observed under long days (16L:8D), but not under short days (8L:16D).

Wool growth, as represented by the weight change per unit area $\left(\mathrm{mg} / \mathrm{cm}^{2}\right)$, was not significantly affected by differences in daylength, but was reduced $(\mathrm{P}<.05)$ by increases in ambient temperature. Wool growth during the 14-wk study is presented in table 4 for each of the six experimental groups.

\section{Discussion}

The data presented herein clearly show an effect of photoperiod and temperature on growth and performance traits of ewe lambs. As producers consider alternative housing for finishing market lambs, the need to identify improved technology and decision-making tools for increased production efficiency becomes apparent. The beneficial effects observed for 16-h photoperiods and 5 to $18 \mathrm{C}$ environmental temperatures in this study provide important information to managerial personnel within the sheep industry.

The detrimental effects of elevated environmental temperatures (Shelton, 1964; Soderquist and Knox, 1967; Hofmeyr et al., 1969) and short daylengths (Forbes et al., 1979; Schanbacher and Crouse, 1980, 1981) have been previously reported. Although photoperiod as an environmental variable in lamb performance has received most of the recent attention, no reports are available to define the relationship between photoperiod and temperature effects on growth, i.e., whether these factors affect lamb performance independently of one another. The present data fail to show important interactions between these two variables on performance characteristics in ewe lambs. Therefore, the remaining discussion presents the influence of these two environmental components separately.
Several, if not most, biological functions of animals are temporally coupled with the rhythmicity of photoperiod (Cloudsley-Thompson, 1976). Photoperiodicity entrains those physiological processes (e.g., endocrine function and basal metabolism) that determine growth rate. Experimental evidence from this (Schanbacher and Crouse, 1980) and other laboratories (Forbes et al., 1979) has clearly demonstrated a differential growth response of lambs exposed to long vs short photoperiods. More recent studies from this laboratory (Schanbacher and Crouse, 1981 ; Schanbacher, 1982) have demonstrated that the incidence (time) of light exposure is as important as the duration of the photoperiod in determining growth rates in lambs. In these studies, male lambs grew as though they were exposed to stimulatory long photoperiods (16L:8D) and not to nonstimulatory short photoperiods (8L:16D) when exposed to an 8-h split photoperiod (7L:9D:1L: 7D). Interestingly, serum prolactin concentrations were elevated in both long and split photoperiods when compared with the short photoperiod.

Results of the present study confirm that ewe lambs also respond to long photoperiods with an enhanced growth rate and increased serum prolactin concentrations. Equally important, however, is the finding that the increased growth rate of male and female lambs is reflected in carcass weight, with no apparent adverse effects on carcass attributes. Although the increase in weight gain without a significant change in carcass composition of ewe lambs exposed to a $16 \mathrm{~L}: 8 \mathrm{D}$ photoperiod is in agreement with the results of a similar study by Forbes et al. (1981), the significant increase in carcass weights of the lambs in the present study was not observed in the study by Forbes et al. (1981). Lack of significance may have resulted from the use of older lambs that were used in some of their experiments or unidentified interactions with other managerial or environmental conditions (e.g., variable temperature).

Body weight gain and feed intake of lambs are depressed by increased temperatures (Kotb and Pfander, 1964). A subsequent report (Knox and Soderquist, 1969) and the present study confirm the detrimental effects of heat exposure on lamb growth and performance. Bhattacharya and Hussain (1974) have described some of the metabolic adjustments made by wether lambs when exposed to elevated 
ambient temperatures. These adjustments included a reduction in daily $\mathrm{N}$ retention without an effect on $\mathrm{N}$ utilization (again, the result of decreased feed intake).

The inverse relationship between environmental temperature and food intake described for shaved and unshaved rabbits by Gasnier and Mayer (1939) has subsequently been described for several species, including goats (Appleman and Delauche, 1958) and sheep (Graham et al., 1959; Bhattacharya and Hussain, 1974). Energy intake is a function of heat loss which is, in part, dependent upon the insulation properties of the skin and wool (fleece). Seasonal variations in wool growth, including fiber diameter and length, have been linked with changes in both daylength and temperature (Thwaites, 1976). Maximum wool growth reportedly occurs in the summer when daylengths and temperatures are greatest. However, results of the present study show maximum wool growth in lambs exposed to cold temperatures. The insignificant effects of photoperiod on wool growth in the present study are in agreement with the conclusion of Hutchinson (1965) that photoperiodic influences only account for a minor portion of the observed seasonal variation in wool growth. Additional studies are warranted to clarify the separate effects of photoperiod and temperature on wool growth.

Regarding the previously proposed hypothesis that environmentally-induced changes in lamb performance might be attributable to changes in circulating levels of the 'anabolic' hormone, prolactin (Schanbacher and Crouse, 1980,1981 ), the present data are less than supportive. As with the previous studies with male lambs, ewe lambs respond to the $16 \mathrm{~L}: 8 \mathrm{D}$ photoperiod with increased serum prolactin. Although these data illustrate that temperatureinduced prolactin secretion is dependent on photoperiod, prolactin levels bear no obvious relationship to treatment differences in lamb performance.

In summary, these results suggest that environmental photoperiod and temperature independently contribute to the growth and performance of confinement-reared ewe lambs and that there is potential for opitmizing both of these variables to improve the efficiency of lamb production. Adjustments in feed intake may contribute to environmentally-induced changes in lamb performance.

\section{Literature Cited}

Appleman, R. and J. C. Delauche. 1958. Behavioral, physiological and biochemical responses of goats to temperature. J. Anim. Sci. 17:326.

Bhattacharya, A. N. and F. Hussain. 1974. Intake and utilization of nutrients in sheep fed different levels of roughage under heat stress. J. Anim. Sci. 38:877.

Cloudsley-Thompson, J. L. 1976. Physiological effects of photoperiodicity on rhythmic processes in animals. In: S. W. Tromp (Ed.) Progress in Human Biometerology. Vol. I, Part II. pp 496-499, 578-580. Swets \& Zeitlinger B. V., Amsterdam.

Forbes, J. M., W. B. Brown, A.G.M. Al-Banna and R. Jones. 1981. The effect of daylength on the growth of lambs. 3. Level of feeding, age of lamb and speed of gut-fill response. Anim. Prod. $32: 23$.

Forbes, J. M., A. A. El Shahat, R. Jones, J.G.S. Duncan and T. G. Boaz. 1979. The effect of daylength on the growth of lambs. 1. Comparisons of sex, level of feeding, shearing and breed of sire. Anim. Prod. 29:33.

Gasnier, A. and A. Mayer. 1939. Recherches sur la regulation de la nutrition. Part III: Mecanismes regulateurs de la nutrition chez le lapin domestique. Ann. Physiol. Physicochim. Biol. 15:186.

Graham, N. McC., F. W. Wainman, K. L. Blaxter and D. C. Armstrong. 1959. Environmental temperature, energy metabolism and heat regulation in sheep. 1. Energy metabolism in closely clipped sheep. J. Agr. Sci. (Camb.) 52:13.

Harvey, W. R. 1975. Least-squares analysis of data with unequal subclass numbers. USDA, ARS Bull. $11-4$.

Hofmeyr, H. S., A. J. Guidry and F. A. Waltz. 1969. Effects of temperature and wool length on surface and respiratory evaporative losses in sheep. J. Appl. Physiol. 26:517.

Hutchinson, J.C.D. 1965. Photoperiodic control of the annual rhythm of wool growth. In: A. G. Lyne and B. F. Short (Ed,) Biology of the Skin and Hair Growth. pp 565-573. Angus and Robertson, Sydney.

Knox, K. L. 1976. Effects of heat on energy metabolism of sheep. In: H. D. Johnson (Ed.) Progress in Animal Biometeorology. Vol. I, Part I. pp 189194. Swets \& Zeitlinger B. V., Amsterdam.

Knox, K. L. and H. G. Soderquist. 1969. Effect of environmental temperature on energy utilization in lambs. J. Anim. Sci. 29:115.

Kotb, A. R. and W. H. Pfander. 1964. Metabolism of sheep under cold and hot conditions. J. Anim. Sci. $23: 1226$.

Schanbacher, B. D. 1980. Influence of testicular steroids on thyrotropin releasing hormone-induced prolactin release in mature rams. J. Androl. 1:121.

Schanbacher, B. D. 1982. Responses of ram lambs to active immunization against testosterone and luteinizing hormone releasing hormone. Amer. $\mathbf{J}$. Physiol. 242:E129.

Schanbacher, B. D. and J. D. Crouse. 1980. Growth and performance of growing-finishing lambs 
exposed to long or short photoperiods. J. Anim. Sci. 51:943.

Schanbacher, B. D. and J. D. Crouse. 1981. Photoperiodic regulation of growth: A photosensitive phase during light-dark cycle. Amer. J. Physiol. 241:E1.

Schanbacher, B. D. and J. J. Ford. 1979. Photoperiodic regulation of ovine spermatogenesis: Relationship to serum hormones. Biol. Reprod. 20:719.

Shelton, M. 1964. Relation of environmental temperature during gestation to birth weight and mortality of lambs. J. Anim. Sci. 23:360.

Soderquist, H. G. and K. L. Knox. 1967. Temperatureenergy relationships in fattening lambs. J. Anim.
Sci. 26:930.

Steel, R.G.D. and J. H. Torrie. 1960. Principles and Procedures of Statistics. McGraw-Hill Book Co., New York.

Thwaites, C. J. 1976. Fiber growth and insulation against heat and cold in sheep. In: H. D. Johnson (Ed.) Progress in Animal Biometeorology. Vol. I, Part I. pp 352-357. Swets \& Zeitlinger B. V., Amsterdam.

Webster, A.J.F. 1976. Effects of cold on energy metabolism of sheep. In: H. D. Johnson (Ed.) Progress in Animal Biometeorology, Vol. I, Part I. pp 218-226. Swets \& Zeitlinger B. V., Amsterdam. 